\title{
Injection safety at primary health care level in south-western Saudi Arabia
}

\author{
A.A. Mahfouz, ${ }^{1}$ I. Abdelmoneim, ${ }^{1}$ M.Y. Khan, ${ }^{1}$ A.A. Daffalla, ${ }^{1}$ M.M. Diab, ${ }^{1}$ H. Shaban ${ }^{1}$
} and H.S. Al Amri ${ }^{1}$

$$
\begin{aligned}
& \text { مأمونية الحَقْن على مستوى مر افت الرعاية الصحية الأولية في جنوب غرب إب المملكة العربية السعودية }
\end{aligned}
$$

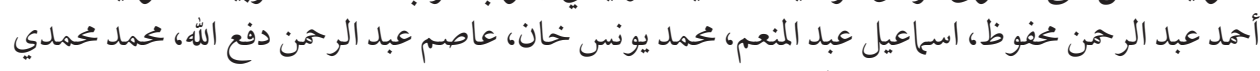

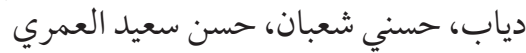

الخلاصسة: استقى الباحثًون بيانات في هذه الدر اسة حول مأمونية الحقن في مديرية الصحة في أبها بالمملكة العربية

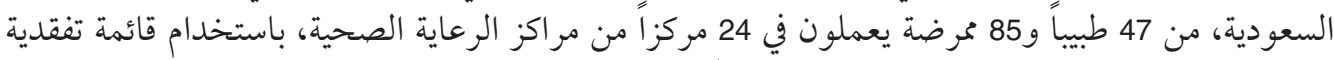

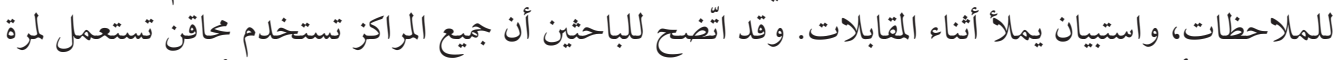

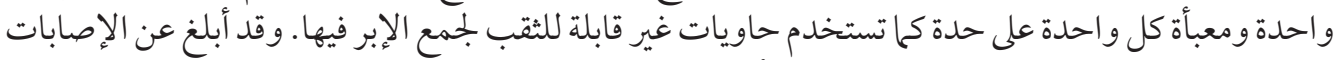

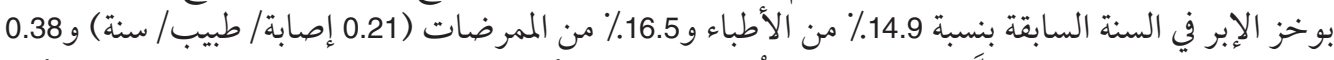

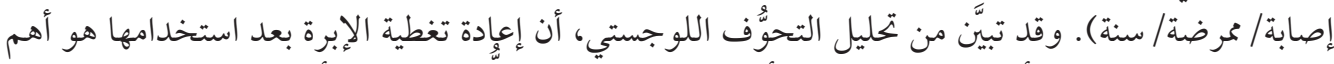

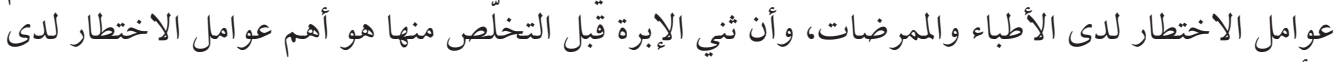
الأطباء.

ABSTRACT In a study of injection safety in Abha health district, Saudi Arabia, data were collected from 47 physicians and 85 nurses at 24 primary health care centres, using an observation checklist and an interview questionnaire. All centres used individually packed disposable syringes and puncture-proof containers to collect used needles. Needlestick injury in the previous year was reported by $14.9 \%$ of physicians and $16.5 \%$ of nurses ( 0.21 and 0.38 injuries/person/year respectively). Logistic regression analysis identified recapping the needle after use (physicians and nurses) and bending the needle before disposal (physicians) as significant risk factors for injury.

\begin{abstract}
Sécurité des injections au niveau des soins de santé primaires dans le sud-ouest de l'Arabie saoudite

RÉSUMÉ Dans le cadre d'une étude sur la sécurité des injections dans le district de santé d'Abha (Arabie saoudite), des données ont été recueillies auprès de 47 médecins et de 85 infirmières dans 24 centres de soins de santé primaires, sur la base d'une grille d'observation et d'un questionnaire d'entretien. Tous les centres utilisaient des seringues jetables en emballage individuel et des récipients imperforables pour recueillir les aiguilles usagées. Au cours de l'année précédente, $14,9 \%$ des médecins et $16,5 \%$ des infirmières avaient signalé des blessures par piqûre d'aiguille (soit respectivement 0,21 et 0,38 blessure par personne et par an). L'analyse de régression logistique a révélé que le fait de reboucher l'aiguille après utilisation (médecins et infirmières) et de plier l'aiguille avant de la jeter (médecins) constituaient des facteurs de risque de blessure significatifs.
\end{abstract}

\footnotetext{
${ }^{1}$ Department of Family and Community Medicine, College of Medicine, King Khalid University, Abha, Saudi Arabia (Correspondence to A.A. Mahfouz: mahfouz@kku.edu.sa).

Received: 29/08/06; accepted: 03/10/06
}

المجلة الصحية لشرق المتوسط، منظمة الصحة العالمية، المجلد الخامس عشر، العدد Y، 9 ·. 


\section{Introduction}

The World Health Organization (WHO) defines safe injection as one that does not harm the recipient, does not expose the health worker to any avoidable risk, and does not result in any waste that is dangerous to the community [1-3]. Needlestick injuries present the single greatest occupational hazard to medical personnel. Unsafe injections are responsible for millions of cases of hepatitis B and C, and an estimated 250000 cases of HIV, annually [4].

Each year some 16000000 million injections are given in developing and transitional countries. The vast majority (95\%) are given for curative care [2]. In certain regions of the world, injections are used far more than really needed, and it is not based on rational medical practice. In some cases, as many as 9 out of 10 patients presenting to a primary health care provider receive an injection, of which over $70 \%$ are unnecessary or could be given in an oral formulation [3]. In such countries patients prefer injections because they believe them to be a stronger and faster method of medication. They also believe that doctors regard injections to be the best treatment. In turn, doctors overprescribe injections because they believe that this best satisfies patients, even though patients are often open to alternatives [5].

Asir region is located in south-west Saudi Arabia with an area of over $80000 \mathrm{~km}^{2}$; Abha city is its capital. Primary health care services in Abha health district are provided through a network of 44 primary health care centres (PHCCs) (10 urban and 34 rural) providing services to 98381 people.

The objectives of the present work were to study the structure and process of injection safety at primary health care level in Abha health district, comparing urban and rural areas, and to study the knowledge, attitudes and practices of primary health care physicians and nurses towards injection safety.

\section{Methods}

Out of the 44 PHCCs in Abha health district, 24 were randomly selected and included in the present study ( 7 urban and 17 rural). Data were collected during April 2006 by Group 30, male 4th-year medical students trained in interviewing skills, and directly supervised by the staff of the Department of Family and Community Medicine. The students attended the health centres during the morning working hours.

The tools used in the present study were a structured standardized observation checklist and an interview questionnaire. Through observation, data were collected about the facilities available for injections, and the collection and disposal of sharp wastes. The interview questionnaire was developed based on a document published by the Safe Injection Global Network (SIGN) and WHO, which has been extensively tested and used in various settings [6].

The second tool was a structured, standardized, self-administered questionnaire for primary health care physicians and nurses, to collect data about their knowledge, attitudes and practices concerning safe injections, collection and disposal of used needles and sharp wastes.

The data were coded and validated. Data entry and analysis were done using SPSS for Windows, version 11. Frequencies, percentages, arithmetic means, modes, medians and standard deviations (SD) were used to present the results. Student $t$-test, chisquared test and Fisher exact 2-tailed test of significance were used at the $5 \%$ level of significance. Multivariate logistic regression analysis was used to identify potential risk factors of needlestick injuries among physicians and nurses, presented as adjusted odds ratio (aOR) and 95\% confidence inter$\operatorname{val}(\mathrm{CI})$. 


\section{Results}

The present study included 47 physicians and 85 nurses working in 7 urban and 17 PHCCs in Abha health district.

\section{Safe injection facilities}

Table 1 shows the data about facilities for safe injections at urban and rural PHCCs in Abha health district. All syringes in both groups of PHCCs were disposable syringes which were individually packed. All necessary disposable syringe volumes $(1,2,3,5$ and $10 \mathrm{~mL}$ ) were available in both groups.

\section{Used needles and sharp wastes collection and disposal}

Table 1 shows that all PHCCs in both groups had the special Ministry of Health $(\mathrm{MOH})$ labelled puncture-proof yellow containers to collect used needles and sharp objects. Yet it was observed that some urban $(n=2$, $28.6 \%)$ and rural centres $(n=7,41.2 \%)$ still used an additional traditional plastic bag in trash cans (which were not closed) in addition to the $\mathrm{MOH}$ yellow containers to collect used needles and sharp wastes. Few urban $(n=1,14.3 \%)$ and rural centres $(n=$ $3,17.6 \%$ ) used disinfectant in the MOH-labelled yellow containers. All PHCCs in both groups were using the services of a special company hired by the $\mathrm{MOH}$ to dispose of used needles and sharp wastes. However, some urban $(n=3,42.9 \%)$ and rural centres ( $n=2,11.8 \%)$ were still disposing of used needles and sharp wastes in the domestic waste or through on-site incineration

\section{Physicians and nurses profile}

Table 2 summarizes the demographic and technical profile of the physicians and nurses. Physicians were found to be significantly older than nurses. Nurses had a significantly higher proportion of females and Saudi nationals compared to physicians. Both groups had a similar average work period in the country of more than 7 years. Few physicians and nurses had attended continuing medical education sessions in the past 3

Table 1 Safe injections and waste collection and disposal profile of the sample of primary health care centres (PHCCs)

\begin{tabular}{|c|c|c|c|c|c|}
\hline \multirow[t]{2}{*}{ Item } & \multicolumn{2}{|c|}{$\begin{array}{l}\text { Urban PHCCs } \\
\quad(n=7)\end{array}$} & \multicolumn{2}{|c|}{$\begin{array}{l}\text { Rural PHCCs } \\
\quad(n=17)\end{array}$} & \multirow[t]{2}{*}{$P$-value ${ }^{a}$} \\
\hline & No. & $\%$ & No. & $\%$ & \\
\hline All syringes disposable and individually packed & 7 & 100.0 & 17 & 100.0 & 1.00 \\
\hline All syringe volumes available ( $1,2,3,5$ and $10 \mathrm{~mL})$ & 7 & 100.0 & 17 & 100.0 & 1.00 \\
\hline $\begin{array}{l}\text { Presence of } \mathrm{MOH} \text { labelled puncture-proof yellow } \\
\text { containers to collect used needles and sharps }\end{array}$ & 7 & 100.0 & 17 & 100.0 & 1.00 \\
\hline Use of a plastic bag in trash cans in addition to & & & & & \\
\hline $\mathrm{MOH}$ yellow containers to collect needles & 2 & 28.6 & 7 & 41.2 & 0.667 \\
\hline Containers to collect needles not closed & 2 & 28.6 & 7 & 41.2 & 0.667 \\
\hline $\begin{array}{l}\text { Use of disinfectants in } \mathrm{MOH} \text { yellow container to } \\
\text { collect needles }\end{array}$ & 1 & 14.3 & 3 & 17.6 & 0.776 \\
\hline $\begin{array}{l}\text { Use of professional company for disposal of } \\
\text { needles and sharp wastes }\end{array}$ & 7 & 100.0 & 17 & 100.0 & 1.00 \\
\hline $\begin{array}{l}\text { Use of domestic waste and incineration locally for } \\
\text { disposal of needles and sharp wastes }\end{array}$ & 1 & 42.9 & 2 & 11.8 & 0.126 \\
\hline
\end{tabular}

${ }^{a}$ Fisher exact test.

$n=$ total number of health centres; $\mathrm{MOH}=$ Ministry of Health.

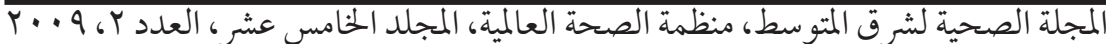


years regarding infection control, safe injections and health care waste disposal.

\section{Physicians and nurses knowledge and attitudes towards safe injections} Regarding knowledge (Table 3), only onethird of nurses $(35.5 \%)$ compared to half of the physicians $(55.3 \%)$ recognized the possibility of injection-associated transmission of all the 3 important diseases (HIV, hepatitis B and C). The difference was statistically significant. On the other hand, the majority of physicians and nurses (more than 85\%) identified the proper method of collecting and disposing needles and sharp objects at primary health settings, with no significant difference between groups. Attitudes towards injection and the perceived preference of patients for injections was different between the groups, with significantly more physicians $(44.7 \%)$ than nurses $(27.1 \%)$ believing that patients preferred injections.

\section{Physicians and nurses safe injection practice}

Table 3 shows that nurses administered an average of 25 injections per week (median
15). The average weekly percentage of physicians' prescriptions including at least 1 injection amounted to $10.4 \%$ with a median percentage of $4.17 \%$.

Almost 1 in 6 physicians (14.9\%) and nurses $(16.5 \%)$ had suffered at least 1 needlestick injury in the past 12 months. The rate of needlestick injuries was 0.38 injuries per person per year among nurses compared to 0.21 among physicians. The difference between groups was not statistically significant.

Similarly, $74.4 \%$ of physicians and $82.4 \%$ of nurses had received at least 3 doses of hepatitis B vaccine. The difference between groups was not significant.

A significantly higher proportion of physicians compared to nurses were injured when recapping the needle with both hands $(59.6 \%$ and $40.0 \%$ respectively) or bending the needle usually before disposing $(31.9 \%$ and $11.8 \%$ respectively). On the other hand, no difference was found between the groups regarding removing the needle before disposing of it $(34.0 \%$ and $31.8 \%$ respectively).

\begin{tabular}{|c|c|c|c|}
\hline Variable & $\begin{array}{l}\text { Physicians } \\
(\mathrm{n}=47)\end{array}$ & $\begin{array}{l}\text { Nurses } \\
(\mathrm{n}=85)\end{array}$ & $P$-value \\
\hline Age [mean (SD) years] & $39.57(8.89)$ & $32.35(8.86)$ & $<0.05 ; t=4.47$ \\
\hline Female sex [No. (\%)] & $14(29.8)$ & $72(84.7)$ & $<0.05 ; \chi^{2}=40.2$ \\
\hline Saudi nationality [No. (\%)] & $9(19.1)$ & $45(52.9)$ & $<0.05 ; \chi^{2}=14.9$ \\
\hline Have postgraduate qualifications [No. (\%)] & $14(29.8)$ & $7(8.2)$ & $<0.05 ; \chi^{2}=10.5$ \\
\hline Time since graduation [mean (SD) years] & $13.72(9.95)$ & $10.07(8.78)$ & $<0.05 ; t=2.27$ \\
\hline $\begin{array}{l}\text { Working period in Saudi Arabia } \\
\text { [mean (SD) years] }\end{array}$ & $9.31(7.67)$ & $7.12(6.77)$ & $\mathrm{NS} ; t=1.91$ \\
\hline $\begin{array}{l}\text { Working period in PHC in Saudi Arabia } \\
\text { [mean (SD) years] }\end{array}$ & $8.07(6.63)$ & $7.06(7.23)$ & $\mathrm{NS} ; t=0.16$ \\
\hline Attended CME on infection control [No. (\%)] & $12(25.5)$ & $11(12.9)$ & $N S ; \chi^{2}=3.35$ \\
\hline Attended CME on injection safety [No. (\%)] & $3(6.4)$ & $8(9.4)$ & $N S ; \chi^{2}=0.34$ \\
\hline Attended CME onwaste disposal [No. (\%)] & $7(14.9)$ & $5(5.9)$ & $N S ; \chi^{2}=2.97$ \\
\hline
\end{tabular}

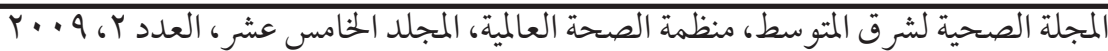


Using logistic regression analysis the following were identified as significant risk factors for needlestick injury: recapping the needle after use using 2 hands by physicians $(\mathrm{aOR}=3.58 ; 95 \% \mathrm{CI}: 1.31-15.71)$ and nurses $(\mathrm{aOR}=2.03 ; 95 \% \mathrm{CI}: 1.11-6.91)$ and bending the needle after use by physicians $(\mathrm{aOR}=2.73 ; 95 \% \mathrm{CI}: 1.11-9.11)$ (Table 4).

\section{Discussion}

WHO defines health care waste as the total waste stream from a health care facility that includes both potentially infectious and non-infectious waste materials [7]. Poor management of health care waste causes serious disease in health care personnel, waste workers, patients and the general public. The main source of illness from infectious waste is probably due to needlestick injuries, which can cause hepatitis $\mathrm{B}$ and $\mathrm{C}$ and HIV. There are, however, numerous other diseases that could be transmitted by contact with infectious health care waste [7].

In early 2006, Asir Directorate of Health Affairs distributed sufficient numbers of special puncture-proof plastic containers in the Asir region to collect used needles, syringes and sharp wastes. The containers were labelled and colour-coded (yellow) with lids to close them. Through a structured programme for medical waste management in the region a special company was recruited to collect medical waste, from urban and rural areas, and dispose of them in a sanitary way using standardized approved techniques.

The present study showed that all PHCCs in urban and rural areas had the special labelled puncture-proof yellow containers to collect used needles and sharp objects and were using the special company provided by the health directorate to dispose of them. Yet it was observed that some centres were also still using additional traditional plastic bags in trash cans and were still disposing of used needles and sharp wastes in the domestic waste or through local incineration.

Our study showed that the availability of individually packed disposable syringes of all volumes at primary health care level in Abha health district was 100\%. This figure contrasts with reports from other developing countries of $34.5 \%$ in India [8] and $42.9 \%$ in Pakistan [9] and shows that the local structure of safety injection is functioning reasonably well. Yet the services need to be fine-tuned, and defects revealed by the present study should be taken into consideration along with the available resources in order to upgrade the quality of the PHC services provided.

On using plastic bags during the handling of domestic wastes, many injuries occur because syringe needles or other sharps have not been collected in rigid puncture-proof containers or due to inappropriate design and overflow of existing sharps containers. Unprotected waste disposal sites increase the risk of exposure of health care workers, waste handlers and the community to needlestick injuries.

Open burning (uncontrolled incineration) of PHC waste should be avoided because of the risk of injury to workers and of uncontrolled emissions to the air, as well as the fact that wastes are often only partially burned. In the last few years there has been growing controversy over the incineration of health care waste. Under some circumstances, including when waste is incinerated at low temperatures (less than $800{ }^{\circ} \mathrm{C}$ ) or when plastics that contain polyvinyl chloride are incinerated, dioxins and furans and other toxic air pollutants may be produced 
Table 3 Safe injection knowledge, attitudes and practices of the physicians and nurses

\begin{tabular}{|c|c|c|c|}
\hline Item & $\begin{array}{l}\text { Physicians } \\
(n=47)\end{array}$ & $\begin{array}{l}\text { Nurses } \\
(n=85)\end{array}$ & Statistical test \\
\hline \multicolumn{4}{|l|}{ Knowledge and attitudes } \\
\hline $\begin{array}{l}\text { HIV, HBV \& HCV can be transmitted from } \\
\text { injections [No. (\% agreeing)] }\end{array}$ & $26(55.3)$ & $30(35.5)$ & $\begin{array}{l}\chi^{2}=4.96 \\
P<0.05\end{array}$ \\
\hline $\begin{array}{l}\text { Needle and sharp objects should be kept in } \\
\text { a puncture-proof container [No. (\% agreeing)] }\end{array}$ & $42(89.4)$ & $72(84.7)$ & $\begin{array}{l}\chi^{2}=0.56 \\
N S\end{array}$ \\
\hline $\begin{array}{l}\text { Needle and sharp objects should be } \\
\text { kept always in a closed container [No. (\% } \\
\text { agreeing)] }\end{array}$ & $43(91.5)$ & $77(90.6)$ & $\begin{array}{l}\chi^{2}=0.03 \\
\quad N S\end{array}$ \\
\hline $\begin{array}{l}\text { Needle and sharp objects wastes should be } \\
\text { disposed of by a professional company not in } \\
\text { domestic waste [No. (\% agreeing)] }\end{array}$ & $43(91.5)$ & $78(91.8)$ & $\begin{array}{l}\chi^{2}=0.01 \\
\text { NS }\end{array}$ \\
\hline $\begin{array}{l}\text { Patients usually prefer injections [No. (\% } \\
\text { agreeing)] }\end{array}$ & $21(44.7)$ & $23(27.1)$ & $\begin{array}{l}\chi^{2}=4.23 \\
P<0.05\end{array}$ \\
\hline \multicolumn{4}{|l|}{ Practices } \\
\hline $\begin{array}{l}\text { No. of injections given during an average } \\
\text { week [mean (SD); median] }\end{array}$ & $1.7(2.3) 1.3$ & $25.5(30.3) 15$ & $\begin{array}{l}t=5.37 \\
P<0.05\end{array}$ \\
\hline $\begin{array}{l}\text { Percentage of prescriptions including at least } \\
1 \text { injection [mean (SD) median] }\end{array}$ & $10.4(16.7) 4.2$ & - & - \\
\hline $\begin{array}{l}\text { Had a needlestick injury in the past year } \\
{[\text { No. }(\%)]}\end{array}$ & 7 (14.9) & $14(16.5)$ & $\begin{array}{l}\chi^{2}=0.06 \\
N S\end{array}$ \\
\hline $\begin{array}{l}\text { No. of needlestick injuries per person per } \\
\text { year [mean (SD)] }\end{array}$ & $0.21(0.54)$ & $0.38(0.93)$ & $\begin{array}{l}t=1.26 \\
\quad \text { NS }\end{array}$ \\
\hline $\begin{array}{l}\text { Had at least } 3 \text { doses of hepatitis B vaccine } \\
{[\text { No. }(\%)]}\end{array}$ & $35(74.4)$ & $70(82.4)$ & $\begin{array}{l}\chi^{2}=1.15 \\
\quad N S\end{array}$ \\
\hline $\begin{array}{l}\text { Recap needle with } 2 \text { hands before disposal } \\
\text { usually [No. (\%)] }\end{array}$ & $28(59.6)$ & $34(40.0)$ & $\begin{array}{l}\chi^{2}=4.66 \\
P<0.05\end{array}$ \\
\hline $\begin{array}{l}\text { Bend needle before disposal usually } \\
{[\text { No. }(\%)]}\end{array}$ & $15(31.9)$ & $10(11.8)$ & $\begin{array}{l}\chi^{2}=8.01 \\
P<0.05\end{array}$ \\
\hline $\begin{array}{l}\text { Remove needle before disposal usually } \\
\text { [No. }(\%)]\end{array}$ & $16(34.0)$ & $27(31.8)$ & $\begin{array}{l}\chi^{2}=0.07 \\
\quad N S\end{array}$ \\
\hline
\end{tabular}

$n=$ total number of staff; $H I V=$ human immunode ficiency virus; $H B V=$ hepatitis $B$ virus; $H C V=$ hepatitis $C$ virus; $S D=$ standard deviation; $N S=$ not significant .

as emissions and/or in fly ash. Exposure to dioxins and furans may lead to adverse health effects, including cancer [10-15].

Our study showed that few centres $(4 \%)$ were adding disinfectants to the containers. Chemical disinfection is generally done by adding bleach or other disinfectants to syringes or other types of infectious wastes. It is not clear whether this is an effective treatment, but in cases where no better option is available such disinfection certainly reduces the risk of infection in case of accidental needlestick injury before transport for further treatment. Disinfection of infectious medical waste can serve as a pretreatment step and may be required prior to employing subsequent treatment technologies, e.g. size reduction by shredding. 
Table 4 Multivariate analysis of potential risk factors for needlestick injuries among primary health care physicians and nurses

\begin{tabular}{lcc}
\hline Risk factor & $\begin{array}{c}\text { Physicians } \\
\text { Adjusted OR (95\% Cl) }\end{array}$ & $\begin{array}{c}\text { Nurses } \\
\text { Adjusted OR (95\% Cl) }\end{array}$ \\
\hline Sex (male versus female) & $0.22(0.19-1.11)$ & $0.49(0.08-2.89)$ \\
Nationality (Saudi versus non-Saudi) & $0.31(0.02-3.23)$ & $1.81(0.92-6.21)$ \\
CME (not attended CME versus attended CME) & $0.37(0.22-4.87)$ & $1.71(0.48-6.75)$ \\
Recap needle with 2 hands before disposal usually & $3.58(1.31-5.71)^{\star}$ & $2.03(1.11-6.91)^{\star}$ \\
Bend needle before disposal usually & $2.73(1.11-9.11)^{\star}$ & $0.93(0.41-3.85)$ \\
Remove needle before disposal usually & $1.29(0.34-11.2)$ & $0.56(0.15-2.73)$ \\
\hline
\end{tabular}

${ }^{*} P<0.05$.

$C M E=$ continuing medical education; $O R=$ odds ratio; $\mathrm{Cl}=$ confidence interval.

However, little information exists on how safe such methods are. On the other hand, when puncture-proof closed containers are being used, the cost-effectiveness of such an approach is questionable [7].

Our study showed that about $15 \%$ of PHC physicians and nurses had experienced needlestick injuries in the previous year, giving rates of 0.21 and 0.38 needlestick injuries per person per year respectively. These figures are almost double the figures of Buraidah [16] and Asir [17] central hospitals in Saudi Arabia, which are are secondary or tertiary hospitals. Differences in facilities, workload, manpower structure and training programmes may explain the difference. Logistic regression analysis showed that the risk factors for needlestick injuries in our study were recapping and bending the needle after giving the injection.

Several suggestions have been made for preventing and limiting sharps injuries among health care workers. These include health education for behaviour change (e.g. about not recapping needles, disposalrelated issues), introduction of barriers to protect the caregiver, safer techniques and devices (e.g. needleless and self-sheathing equipment) and improved organizational factors (e.g. better staffing levels). However, the cheapest, easiest and most effective method of reducing sharps injuries is through health education, leading to changes in behaviour [18].

Continuing education and training programmes for primary health care physicians and nurses are recommended to keep them up-to-date and aware of new safe injection policies, practices and procedures. These programmes should be based on further studies assessing health care workers actual and felt needs in relevant areas.

\section{References}

1. Kotwal A. Innovation, diffusion and safety of a medical technology: a review of the literature on injection practices. Social science and medicine, 2005, 60:113347.

2. Hutin $Y$ et al. Best infection control practices for intradermal, subcutaneous, and intramuscular needle injections. Bulletin of the World Health Organization, 2003, 81(7):491-500.

3. Simonsen $L$ et al. Unsafe injections in the developing world and transmission of blood borne pathogens: a review. Bulletin 
of the World Health Organization, 1999, 77(10):789-800.

4. Annex Table 3. Burden of disease in disability-adjusted life years (DALYs) by of the World Health Organization, 1999, 77(10):789-800.

4. Annex Table 3. Burden of disease in disability-adjusted life years (DALYs) by cause, sex and mortality stratum in WHO Regions: estimates for 2000. In: The world health report 2001. Mental health: new understanding, new hope. Geneva, World Health Organization, 2001.

5. Reeler A. Anthropological perspectives on injections: a review. Bulletin of the World Health Organization, 2000, 78(1):13543.

6. Injection practices: rapid assessment and response guide. Geneva, World Health Organization, 2000:1-35 (WHO/ BCT/02.11).

7. Management of solid health-care waste at primary health-care centres: a decisionmaking guide. Geneva, World Health Organization, 2004 (WHO/PHE/IVB/04/01).

8. Rajasekaran $\mathrm{M}$ et al. Injection practices in southern part of India. Public health, 2003, 117:208-13.

9. Raglow J, Luby SP, Nabi N. Therapeutic injections in Pakistan: from the patients' perspective. Tropical medicine and international health, 2001, 6:69-75.

10. Prüss A, Giroult E, Rushbrook $P$, eds. Safe management of wastes from health- care activities. Geneva, World Health Organization, 1999.

11. Wastes from health-care activities. Geneva, World Health Organization, 2000 (Reviewed November 2007) (Fact Sheet No. 253).

12. Batterman S. Findings on the assessment of small-scale incinerators for health care waste. Geneva, World Health Organization, 2004 (WHO/SDE/WSH/04.07).

13. Safe health-care waste management: policy paper. Geneva, World Health Organization, 2004.

14. Management of waste from immunization activities. Geneva, World Health Organization, 2004.

15. Health-care waste management. Geneva, World Health Organization, 2004 (Fact Sheet No. 281).

16. Jahan S. Epidemiology of needlestick injuries among health care workers in a secondary care hospital in Saudi Arabia. Annals of Saudi medicine, 2005, 25:233-8.

17. Ghamdi $S$ et al. Needle stick and sharp injuries at Asir Central Hospital, Abha, Saudi Arabia. Annals of Saudi medicine, 2003, 23:404-7.

18. Hanrahan A, Reutter L. A critical review of the literature on sharps injuries: epidemiology, management of exposures and prevention. Journal of advanced nursing, 1997, 25(1):144-54. 